\title{
Academic resilience for preservice teachers among field of sciences: A measurement scale in education
}

\author{
Muhammmad Bukhori Dalimunthe ${ }^{1}$, Ery Tri Djatmika², Heri Pratikto ${ }^{3}$, Puji Handayati ${ }^{4}$, Rosmala \\ Dewi $^{5}$, Siti Salina Mustakim ${ }^{6}$ \\ ${ }^{1,2,3,4}$ Department of Economics Education, Universitas Negeri Malang, Indonesia \\ ${ }^{5}$ Department of Guidance and Counseling, Universitas Negeri Medan, Indonesia \\ ${ }^{6}$ Department of Foundation Studies, Universiti Putra Malaysia, Malaysia
}

\section{Article Info}

Article history:

Received Mar 6, 2021

Revised Aug 27, 2021

Accepted Sep 10, 2021

\section{Keywords:}

Adaptive

Commitment

Composure

Control

Coordination

Empathy

Perseverance

\begin{abstract}
The scale of measuring academic resilience in a decade has experienced rapid development. Numerous instruments have been formulated by previous researchers, but it has not explicitly measured the academic resilience for preservice teachers. The purpose is to construct a new measure of academic resilience for preservice teachers, which consists of two stages: the validity and reliability of the instrument; and continued with differences in academic resilience for preservice teachers among the fields of social, science, and language. Measurement instruments were given to lectures (eight experts) and students $(n=236)$ from various universities in Medan, Indonesia. The content validity used V-Aiken, and construct validity used confirmatory factor analysis; reliability using the interclass correlation coefficient and internal consistency reliability. The results show that the constructs of composure, commitment, control, coordination, empathy, perseverance, and adaptive have excellent and accurate validity and reliability to measure academic resilience. The findings are specific that there are significant differences in the academic resilience for preservice teachers among field of sciences. Researchers imply that they can use these instruments appropriate and responsive to academic resilience for preservice teachers highlighting among the sciences' domain so that future research can be carried out to explore these differences.
\end{abstract}

This is an open access article under the CC BY-SA license.

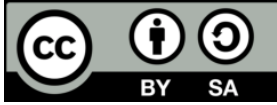

Corresponding Author:

Muhammad Bukhori Dalimunthe

Department of Economics Education

Universitas Negeri Malang

Jalan Semarang 5, 651145, Malang, Indonesia

Email: daliori86@unimed.ac.id

\section{INTRODUCTION}

Preservice teachers are agents of change who seek to continue and improve education quality to prepare generations ready for change. On the way to studying on campus, students have dynamically faced with various challenges and difficulties. It may have various impacts related to stress, anxiety, avoidance, health, well-being, problems on-campus attendance, learning readiness, hindering learning progress, and even refusal to study [1]-[4]. Some of these problems are acute, causing failure or dropping out from campus, showing early signs of student anxiety in facing minor problems. Students routinely face problems every day related to anxiety, avoidance of assignments, and difficulty in self-control, referred to as 'academic buoyancy, must get serious attention from teachers and campus leaders [5]. If these problems have ignored, it will cause 
failure or a negative impact on physical and psychological development [6]. Resilience theory offers a concepts for understanding how adolescents develop and successfully face risks and challenges [7]-[9].

Academic resilience is defined as students' ability to rise again using assets from internal and external support to face adversity during difficult times so that they can escape from adversity and achieve academic success. The presence of academic resilience as a stimulus and guardian of students' psychological development is increasingly meaningful to prepare their abilities and fighting power to face academic problems. Academic resilience can be constructed from internal and external influences related to learning development. Internal factors consisting of composure, commitment, control, coordination, empathy, perseverance, and adaptive are factors that have mostly studied in various resilience research [5], [10]-[14]. Likewise with external factors which consist of environment, support from teachers, peers, and parents [15][17], culture [18], [19], classroom or campus climate [20], learning regulations that apply on campus [21], [22], curriculum [23]-[25]. Internal factors shaping academic resilience have been explored in this paper.

During the last two decades, many researchers have developed resilience measurement instruments, especially in the academic field as shown in Table 1. Various forms of academic resilience measurement scales have been generated with topics around academia and education as Martin and Marsh [14] measuring the academic resilience of high school students aged 11 and 12 in Australia related to psychology and education as predicted by self-efficacy, control, planning, anxiety, and persistence, for which the measurement scale is named 'Academic Resilience'. Seven years later, Martin [5] explored the differences and limitations of academic buoyancy and academic resilience which resulted in the academic risk and resilience scale (ARRS) measurement scale which was carried out at junior high to senior high in Australia. Furthermore, Hanson and Kim [12] measured youth resilience and development in primary and secondary education students in terms of environmental aspects (such as school, home, community, and peers) and internally known as the resilience and youth development module (RYDM). The same resilience measurement was also carried out by Sarwar, et al. [26] to measure resilience to middle-level students in Pakistan through the dimensions of personal competence, social competence, family, personal structure, and social support.

Table 1. Development of academic resilience instruments from 2006-2019

\begin{tabular}{|c|c|c|}
\hline Authors & Items & Indicator \\
\hline Martin and Mars [14], Academic resilience & 6 & $\begin{array}{c}\text { Confidence } \\
\text { Coordination } \\
\text { Control } \\
\text { Composure } \\
\text { Commitment }\end{array}$ \\
\hline \multirow{10}{*}{$\begin{array}{l}\text { Hanson and Kim [12], Resilience and youth } \\
\text { development module (RYDM) }\end{array}$} & 9 & Environmental - School assets \\
\hline & 9 & Environmental - Home assets \\
\hline & 9 & Environmental - Community assets \\
\hline & 9 & Environmental - Peer assets \\
\hline & 3 & Internal - Cooperation and communication \\
\hline & 3 & Internal - Self-efficacy \\
\hline & 3 & Internal - Empathy \\
\hline & 3 & Internal - Problem-solving \\
\hline & 3 & Internal - Self-awareness \\
\hline & 3 & Internal - Goals and aspirations \\
\hline \multirow[t]{5}{*}{ Sarwar, et al. [26], Resilience scale } & 11 & Personal competence \\
\hline & 7 & Social competence \\
\hline & 6 & Family competence \\
\hline & 5 & Personal structure \\
\hline & 4 & Social support \\
\hline Martin [5] & 4 & Academic risk and resilience scale \\
\hline \multirow[t]{3}{*}{ Cassidy [10], Academic resilience scale (ARS-30) } & 14 & Perseverance \\
\hline & 9 & Reflecting and adaptive help-seeking \\
\hline & 7 & Negative effect and emotional response \\
\hline \multirow{7}{*}{ Resilience at university (RAU) } & 3 & Living authentically \\
\hline & 4 & Finding your calling \\
\hline & 3 & Maintaining perspective \\
\hline & 4 & Managing stress \\
\hline & 2 & Interacting cooperatively \\
\hline & 2 & Staying healthy \\
\hline & 2 & Building networks \\
\hline \multirow{4}{*}{$\begin{array}{l}\text { Chisholm-Burns, et al. [11], Academic resilience } \\
\text { among pharmacy students (ARPS) }\end{array}$} & 5 & Negative affect and emotional response \\
\hline & 5 & Reflecting and adaptive help-seeking \\
\hline & 3 & Adaptive thought processes \\
\hline & 3 & Perseverance \\
\hline
\end{tabular}


After 2010, scholars began to highlight academic resilience for students on campus. The measurement of academic resilience constructed by Cassidy [10] is better known as 'the academic resilience scale (ARS-30)', which is mainly used by researchers from around the world. Initially, ARS-30 was tested on undergraduate students at various British universities, which resulted in three factors that have been reduced from 30 items: perseverance, reflecting and adaptive help-seeking and negative affect and emotional response. Furthermore, Resilience at University (RAU) developed by Turner, Holdsworth, and Scott-Young [13] was tested on undergraduate students from Applied Sciences in Australia, which resulted in seven reduced factors from 20 items: living authentically, finding your calling, maintaining perspective, managing stress, interacting cooperatively, staying healthy, building networks. Then, the development of the measurement of academic resilience among pharmacy students (ARPS) by Chisholm-Burns, et al. [11] combines ARS-30 and short grit scale (Grit-S), developed by DucFworth and Quinn [27], which was tested on undergraduate pharmacy students who produced four factors: negative affect and emotional response, reflecting and adaptive help-seeking, adaptive thought processes, perseverance. The measurement of the academic resilience scale that prior researchers have done has not comprehensively targeted the preservice teachers. The development of the measurement of academic resilience for students becomes the urgency and renewal of instruments that can provide new insights for academics and practitioners who focus on current issues of preservice teachers' resilience.

Therefore, this study formulates a research question on how to measure the academic resilience of preservice teachers in the field of sciences. The purpose of this paper is to develop a new measure of academic resilience for preservice teachers', which consists of two stages: i) The validity and reliability of the instrument; and ii) Continued testing the differences in the academic resilience of preservice teachers among the fields of social, science, and language. The next section will describe the methods, findings, and implications comprehensively described.

\section{RESEARCH METHOD}

\subsection{Research design}

Students in the field of educational studies are the source of the data in this paper. Preservice teachers come from various fields of social, science, and languages studying at Universitas Negeri Medan, Universitas Muslim Nusantara Al-Washliyah, Universitas Muhammadiyah Sumatera Utara, and Universitas HKBP Nommensen located in Medan, Indonesia. These campuses are mandated to carry out the teacher professional training (TPT) program. It is a training program for teachers from the Ministry of Education and Culture, so it deserves to be a source of information in this research. The involvement of these campuses in the TPT program, of course, the education curriculum is superior to creating quality teachers. These campuses are better than other campuses with other education and teacher study programs domiciled in Medan, is the main reason. The research design used ex post facto through two stages. The first, measuring the validity and reliability of the instrument; and continued with differences in academic resilience for preservice teachers among the fields of social, science, and language.

\subsection{Respondents}

Respondents came from preservice teachers from the fields of social (Department of Economic Education; $n=391$ ), science (Department of Mathematics Education; $n=704$ ), and languages (Department of Indonesia Language Education; $n=607$ ). The population of 1,702 came from fourth-year students from all campuses involved in this research. Researcher using purposive sampling for collecting the data. The targeted respondents are preservice teachers who have completed an internship at a school who are assumed to have good abilities to become teachers. The collecting sample required the representation of each department at the universities. The sample size of 324 was determined using Slovin's formula [28]. The survey instrument was distributed in January 2020 and collected 236 data. The respondents consist of social, science, and languages fields at the Universitas Negeri Medan (32; 24; 28), Universitas Muslim Nusantara Al-Washliyah $(17 ; 17 ; 14)$, Universitas Muhammadiyah Sumatera Utara $(20 ; 23 ; 21)$, and Universitas HKBP Nommensen $(10 ; 14 ; 16)$. The data collected was sufficient for testing construct validity and internal consistency using confirmatory factor analysis (CFA). The minimum sample size requirement on CFA with the criteria of seven constructs, the significance of $5 \%$, and an assumption of a statistical power level of $80 \%$, it is recommended that 166 observational data [29]. Furthermore, other calculations to determine the recommended sample size by Hair, et al. [29] using the G Power application with the criteria of the seven predictors tested, the significance of $5 \%$, and the type of power analysis using post hoc showed the sample of 145 respondents. Thus the amount of data collected has exceeded the minimum sample size so that testing to continue on the measurement of the academic resilience instrument of preservice teachers. 


\subsection{Instruments}

The academic resilience measurement scale was developed based on indicators from various literature and research from several researchers [10]-[12], [14]. There are 14 items academic resilience instruments constructed by composure (two items), commitment (two items), control (two items), coordination (two items), empathy (two items), perseverance (two items), and adaptive (two items). This has been determined and then translated into items tailored to preservice teachers' characteristics and academic type. The items used can reflect the academic resilience of preservice teachers'. Lecturers are involved in testing the content validity and reliability intraclass correlation coefficient (ICC) to provide judgments on the relevance of all instrument items and provide improvements (if needed). The lecturers consisted of two education experts and six science experts representing the departments of each campus involved in this research, so there were eight experts.

\subsection{Data analysis}

Based on the data collected, validity was carried out to measure accuracy and reliability to measure constancy of instrument academic resilience. Furthermore, the t-test (SPSS version 18) used to measure differences in academic resilience among preservice teachers from the fields of social, science, and language, explicitly described in the discussion section. In the first stage, testing the content validity using V-Aiken, the instrument consists of four categories (irrelevant, less, sufficient, relevant). Testing construct validity uses CFA (Smart PLS version 3.0), an academic resilience instrument consisting of five categories (poor, fair, good, very, excellent) Likert scale used to assess student response rates. Reliability testing among experts using the ICC, the instrument consists of four categories (irrelevant, less, sufficient, relevant). Reliability testing uses internal consistency (Smart PLS version 3.0), the academic resilience instrument consists of five categories (poor, fair, good, very, excellent) the Likert scale is used to assess student response levels. In the final stage, differences in academic resilience are made between science fields using the t-test (SPSS version 18). Academic resilience instruments should measure the differences in the resilience of preservice teachers from the fields of social, science, and language.

The content validity criterion compares the V-Aiken mean score with the category of the instrument's accuracy level measuring the academic resilience of preservice teachers. The score is less than .4 then it is interpreted that the validity is "low"; a score between .4-.8, it is interpreted that the validity is "moderate"; the score is more significant than .8, it is interpreted that the validity is "high" [30]. The criteria for construct validity are using average variance extracted (AVE), in which all constructs must be greater than .5 [29]. The criteria for measuring inter-rater reliability using an ICC score between .5-.79, the measuring instrument has adequate stability; if the ICC score is more significant than .8 then the measuring instrument has high stability [31], [32]. Internal consistency reliability criteria use outer loading, where all constructs must be higher than .708 [29].

\section{RESULTS}

There were 236 respondents participated in this study, most of them were female (58\%). Respondents were dominated by social, language, and science, respectively, spread across several campuses in Medan, Indonesia. Respondents were studying at Universitas Negeri Medan, Universitas Muhammadiyah Sumatera Utara, Universitas Al-Washliyah Muslim Nusantara, and Universitas HKBP Nommensen. The distribution of respondents has been proportional to the number of preservice teachers on these campuses. Most of the student domiciles come from areas outside the city, and most of them rent housing. The characteristics of the respondents are shown in Table 2.

Based on the data collected, the construct variables consisting of composure, commitment, control, coordination, empathy, perseverance, and adaptive have high validity and excellent reliability (in the first stage) to test the accuracy and reliability of measuring the academic resilience of teacher students. Also, testing resilience based on social, science, and language found significant differences in academic resilience (in the second stage). This provides novelty for research progress, which has positive implications for researchers to explore this issue more broadly. Descriptive statistics are shown in Table 3.

Based on the descriptive statistics, it is known that the highest mean value of construct variables is the coordination, composure, perseverance, adaptive, commitment, control, and empathy, respectively. Meanwhile, the highest average scores are in science, language, and society, when viewed from the field of sciences. Furthermore, the validity and reliability test results have been obtained, described in the first stage, and t-test for preservice teachers' academic resilience between the fields described in the second stage. 
Table 2. The characteristics of the respondents

\begin{tabular}{lll}
\hline \multicolumn{1}{c}{ Characteristics } & \multicolumn{1}{c}{ Value $(\%)$} \\
\hline Gender & Male & $100(42 \%)$ \\
& Female & $136(58 \%)$ \\
& Social & $79(33.5 \%)$ \\
& Language & $79(33.5 \%)$ \\
Campuses & Science & $78(33.0 \%)$ \\
& Universitas Negeri Medan & $84(36 \%)$ \\
& Universitas Muhammadiyah Sumatera Utara & $64(27 \%)$ \\
& Universitas Muslim Nusantara Al-Washliyah & $48(20 \%)$ \\
Domiciles & Universitas HKBP Nommensen & $40(17 \%)$ \\
& Medan city & $80(34 \%)$ \\
& Comer & $156(66 \%)$ \\
& Own & 0 \\
& With relatives & $72(30 \%)$ \\
& Rent & $164(70 \%)$ \\
\hline
\end{tabular}

Table 3. Descriptive statistics

\begin{tabular}{lcccccccc}
\hline & $\mathrm{N}$ & Min & Max & Mean & SD & Variance & Skew & Kurtosis \\
\hline Academic resilience & 236 & 18.76 & 54.32 & 37.8545 & 7.68697 & 59.090 & -.186 & -.824 \\
Composure & 236 & 2.00 & 8.06 & 5.5348 & 1.64656 & 2.711 & -.229 & -.709 \\
Commitment & 236 & 2.00 & 8.11 & 5.3630 & 1.49179 & 2.225 & -.149 & -.306 \\
Control & 236 & 2.00 & 7.95 & 5.1993 & 1.64138 & 2.694 & -.156 & -.553 \\
Coordination & 236 & 2.00 & 8.27 & 5.8329 & 1.50013 & 2.250 & -.075 & -.718 \\
Empathy & 236 & 2.00 & 8.00 & 5.0803 & 1.48271 & 2.198 & .085 & -.365 \\
Perseverance & 236 & 2.00 & 7.76 & 5.4793 & 1.47918 & 2.188 & -.292 & -.417 \\
Adaptive & 236 & 2.00 & 7.96 & 5.3696 & 1.54171 & 2.377 & -.111 & -.515 \\
Social & 79 & 18.76 & 52.33 & 34.7510 & 7.87734 & 62.052 & .294 & -.572 \\
Language & 79 & 21.83 & 54.32 & 37.9066 & 7.40132 & 54.780 & -.138 & -.688 \\
Science & 78 & 26.47 & 53.01 & 40.9449 & 6.51377 & 42.429 & -.587 & -.455 \\
\hline
\end{tabular}

\subsection{The first stage: Validity and reliability}

\subsubsection{Content validity}

The content's validity involved experts in the field of education and teacher training from the campuses involved in this research which consisted of eight experts, each campus consisting of two experts. V-Aiken was used to test the content validity. It was found that $50 \%$ of the items $(1,3,6,8,10,11,12)$ were in the high category, while the rest were in the moderate category. The V-Aiken mean is .807 , so the instrument has a high level of validity. This provides information that the construct variables described through the questionnaire items have a high degree of accuracy to measure preservice teachers' academic resilience. Table 4 shows the detail of the content validity.

Table 4. Content validity

\begin{tabular}{|c|c|c|c|c|c|c|c|c|c|c|}
\hline Item & $\mathrm{R} 1$ & $\mathrm{R} 2$ & R3 & $\mathrm{R} 4$ & R5 & R6 & R7 & $\mathrm{R} 8$ & $\mathrm{~V}$ & Category \\
\hline 1. I can change the mood when I need it. & 4 & 4 & 4 & 4 & 4 & 4 & 4 & 4 & 1.00 & High \\
\hline 3. I will make an effort to learn and maintain achievements. & 3 & 3 & 3 & 4 & 3 & 4 & 4 & 4 & .83 & High \\
\hline $\begin{array}{l}\text { 5. Adequate rest to maintain strength and energy when I } \\
\text { study on campus. }\end{array}$ & 3 & 3 & 3 & 3 & 3 & 3 & 3 & 3 & .67 & Moderate \\
\hline 6. I can control learning difficulties on campus. & 4 & 4 & 4 & 4 & 4 & 4 & 4 & 4 & 1.00 & High \\
\hline 8. I discussed the assignment with the lecturer. & 4 & 4 & 4 & 4 & 4 & 4 & 4 & 4 & 1.00 & High \\
\hline $\begin{array}{l}\text { 9. I try to understand the learning difficulties that my peers } \\
\text { experience. }\end{array}$ & 3 & 3 & 3 & 3 & 3 & 3 & 3 & 2 & .63 & Moderate \\
\hline $\begin{array}{l}\text { 10. I try to understand the learning success that friends feel } \\
\text { and think. }\end{array}$ & 4 & 4 & 4 & 4 & 4 & 4 & 4 & 4 & 1.00 & High \\
\hline $\begin{array}{l}\text { 14. I try to explore the strengths and weaknesses of learning } \\
\text { in order to become a qualified teacher. }\end{array}$ & 3 & 3 & 3 & 3 & 3 & 3 & 3 & 3 & .67 & Moderate \\
\hline
\end{tabular}




\subsubsection{Construct validity}

Construct validity involves preservice teachers $(n=236)$ who have various areas of expertise from campuses involved in the study. The criterion for construct validity at the AVE value must be greater than .5 . Table 5 shows that all constructs have an AVE value greater than .5, and then the constructs consisting of composure, control, adaptive, coordination, perseverance, commitment, and empathy, respectively, have reflectively measured the academic resilience. The validity findings through the content and construct have provided confidence and information that the new resilience measurement scale has a very high accuracy for measuring academic resilience for preservice teachers.

Table 5. Outer loading of academic resilience constructs

\begin{tabular}{|c|c|c|c|}
\hline Constructs & Loading factor & AVE & Discriminant \\
\hline Composure & & .753 & .868 \\
\hline Item 1 & .860 & & \\
\hline Item 2 & .875 & & \\
\hline Commitment & & .613 & .783 \\
\hline Item 3 & .788 & & \\
\hline Item 4 & .778 & & \\
\hline Control & & .744 & .863 \\
\hline Item 5 & .880 & & \\
\hline Item 6 & .845 & & \\
\hline Coordination & & .626 & .791 \\
\hline Item 7 & .753 & & \\
\hline Item 8 & .828 & & \\
\hline Empathy & & .604 & .777 \\
\hline Item 9 & .803 & & \\
\hline Item 10 & .749 & & \\
\hline Perseverance & & .615 & .784 \\
\hline Item 11 & .850 & & \\
\hline Item 12 & .712 & & \\
\hline Adaptive & & .659 & .812 \\
\hline Item 13 & .822 & & \\
\hline Item 14 & .801 & & \\
\hline
\end{tabular}

\subsubsection{Inter rater reliability}

Experts who are engaged to perform reliability testing have the same role of testing validity. The experts were eight experts who give judgment from weak to excellent levels using a Likert scale of 1-5. The value of the intraclass coefficient correlation (ICC) is used to determine the measuring instrument's stability. The test results are shown in Table 6 show that the ICC value of .837 so is more significant than .8 , and then the scale measuring the academic resilience of preservice teachers has high stability.

Table 6. Cronbach's alpha, composite reliability, and ICC

\begin{tabular}{lllll}
\hline & Cronbach's & Composite & ICC & Evidence \\
\hline Academic resilience & .847 & 8.876 & .837 & Reliable \\
\hline
\end{tabular}

\subsubsection{Internal consistency reliability}

Internal consistency reliability was tested through CFA. The test results obtained that the loading factor value of all items is more significant than .708 a shown in Figure 1 or Table 5 so that all items have outstanding reliability to measure academic resilience for preservice teachers. Based on Figure 1, the most significant coefficient value is in the control construct, followed by coordination, composure, commitment, perseverance, empathy, and adaptive, respectively. Internal consistency reliability can also be tested through Cronbach's alpha value. Based on Table 6, Cronbach's Alpha has a value greater than .7, so the reliability interpretation is in the excellent category [31].

The intraclass coefficient correlation findings and the internal consistency lead to an excellent level category. The constructs that have been tested for reliability provide knowledge that has high-grade reliability to measure preservice teachers' academic resilience. The Smart PLS 3.0 output also provides information about the t-statistic value shown in Table 7. The significance value less than .05 indicates that all construct variables effectively predict the academic resilience of preservice teachers. The t-statistic value can also be used to continue testing the regression or structural equation model, which the subsequent researchers can do. 
Table 7. The value of t-statistic

\begin{tabular}{lcc}
\hline \multicolumn{1}{c}{ Constructs } & $\mathrm{t}$ & $\mathrm{p}$-value \\
\hline Composure & 20.938 & .000 \\
Commitment & 22.586 & .000 \\
Control & 28.628 & .000 \\
Coordination & 22.299 & .000 \\
Empathy & 14.191 & .000 \\
Perseverance & 18.238 & .000 \\
Adaptive & 11.951 & .000 \\
\hline
\end{tabular}

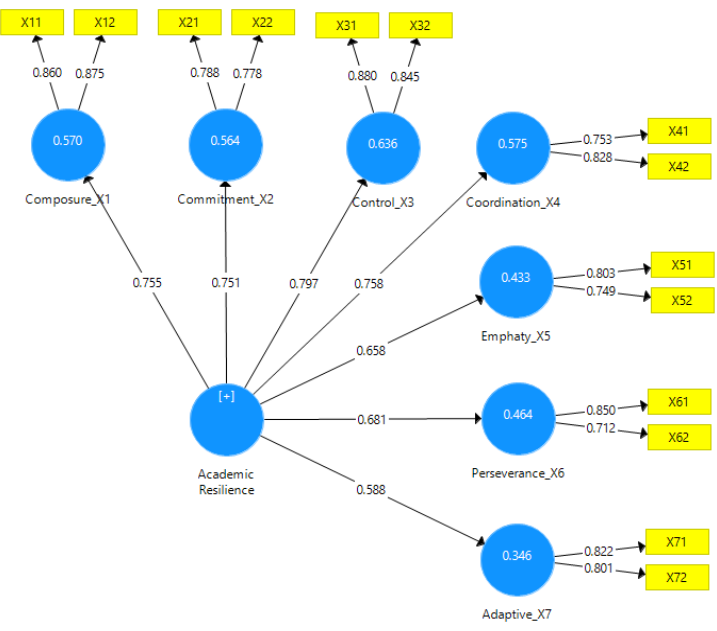

Figure 1. Output of PLS algorithm of academic resilience construct

\subsection{Second stage: Academic resilience of preservice teachers among the fields of science}

At this stage, the researcher wants to prove more broadly that the instrument for measuring preservice teachers' academic resilience can test the differences in resilience between social, science, and language. The initial step is viewed from the test of data homogeneity requirements which can be seen in Table 8. A significance value greater than .05 indicates that the data comes from various characteristics or is heterogeneous. So, that further testing can be done. The test results showed that there are differences in the academic resilience of preservice teachers among social, science, and language, which can be seen from the significant value less than .05 and the value of the F-statistic greater than the criteria as shown in Table 9.

Table 8 . Test of homogeneity of variances

\begin{tabular}{cccc}
\hline Levene statistic & df1 & df 2 & Sig. \\
\hline 1.823 & 2 & 233 & .164 \\
\hline
\end{tabular}

Table 9. The result of Anova test

\begin{tabular}{ccccc}
\hline & Sum of squares & df & Mean square & F \\
\hline Between groups & 1506.088 & 2 & 753.044 & 14.173 \\
Within groups & 12379.945 & 233 & 53.133 & \\
Total & 13886.033 & 235 & & \\
\hline
\end{tabular}

Specifically, the differences between science fields can be seen from the significance value smaller than .05 , which is shown in Table 10. Preservice teachers in the social have significant differences in academic resilience between science (.000) and language (.019); science has a significant difference in academic resilience between social (.000) and language (.026); the language field has a significant difference in academic resilience between social (.19) and science (.026).

The academic resilience of preservice teachers between science fields can be seen from the average value. The mean score in science is higher than the others than on language and social as shown in Table 3. High academic resilience is in line with the learning challenges faced by students. Science students have higher learning challenges when compared to language and social, as well as academic resilience. The more resilient preservice teachers are in science, language, and social, respectively.

Int J Eval \& Res Educ, Vol. 10, No. 4, December 2021: 1262 - 1271 
Table 10. Multiple comparisons - Tukey HSD

\begin{tabular}{ccccc}
\hline (I) $\mathrm{Z}$ & $(\mathrm{J}) \mathrm{Z}$ & Mean difference (I-J) & Std. Error & Sig. \\
\hline Social & Science & $-6.19395^{*}$ & 1.16351 & .000 \\
& Language & $-3.15561^{*}$ & 1.15980 & .019 \\
Science & Social & $6.19395^{*}$ & 1.16351 & .000 \\
& Language & $3.03834^{*}$ & 1.16351 & .026 \\
Language & Social & $3.15561^{*}$ & 1.15980 & .019 \\
& Science & $-3.03834^{*}$ & 1.16351 & .026 \\
\hline *The mean difference is significant at the .05 level & &
\end{tabular}

\section{DISCUSSION}

Numerous researchers have investigated academic resilience, but no measurement scale focuses explicitly on preservice teachers. This research complements the findings of previous researchers who measure academic resilience [10], [11], [13], [14]. Thus, we see this as an opportunity and a challenge to measure preservice teachers' academic resilience with various construct variables that theoretically affect student resilience development. Preservice teachers' academic resilience is constructed by composure, commitment, control, coordination, empathy, perseverance, and adaptive.

The first stage is to test the validity obtained by the expert's assessment that the content validity reveals that the academic resilience instrument has high validity. It is believed to have a high level of accuracy to measure academic resilience. Likewise, testing the validity of the construct and the findings of the validity of the content revealed that the instrument had high accuracy for measuring academic resilience for preservice teachers. Furthermore, the inter-rater reliability test was carried out from the expert's assessment showing high-reliability results. It is in line with the internal consistency reliability test, which shows that the instrument has excellent reliability for measuring preservice teachers' academic resilience. The findings in this research complement previous research [10], [14], which in this research involved empathy and adaptive. Both constructs have been statistically proven in developing academic resilience for preservice teachers.

The findings obtained in the first stage provide new insights for the development of resilience research that focuses on preservice teachers' academic problems. Preservice teachers have the characteristics of the knowledge and skills they experience at the time of the study. They are given various scientific knowledge (social, science, language) and classroom teaching skills through field experience programs. Various academic challenges and problems cannot avoid in the classroom and environmental learning [5], so students must prepare physically and psychologically resiliently. The construct variables in this research are assets in academic resilience that play an essential role in dealing with various academic anxieties and challenges [33]. These assets are promotive factors to develop resilience that compensate for the risks [34].

The second stage continued examining the differences in preservice teachers' academic resilience grouped into social, science, and language. The Anova test results show that there are differences in the academic resilience of teacher students. The different test based on the group of areas of sciences shows differences in academic resilience between fields of sciences, as evidenced by Tukey HSD. These findings have differences that establish and complement previous research exposed by Chirsholm-Burns, et al. [11] and Turner, Holdsworth, and Scott-Young [13]. This research highlights preservice teachers as subjects with various scientific fields inherent in their abilities each preservice teacher. Previous researchers have focused on pharmacy students [11] and students' mental health and well-being [13].

Next, to trace the students more resilient by fields of science can be seen from the mean values (Table 3), to obtain a higher science student resilience level, then continued social and language students, respectively. The level of difficulty and complexity in science is more compared to other fields of sciences. Numerical and verbal skills must be understood by the science field [35], [36]. On the other hand, language and social skills do not prioritize these abilities specifically. Likewise, the curriculum in the science department applies intensive and practical learning, especially for high-level students [37]. So, they tend to experience considerable stress when compared to preservice teachers from another department. Furthermore, the field of language has a mastery of literacy that is more difficult than social expertise. Local students studying a Department of Foreign Language, such as English, French, German, and Arabic must master conversation and good grammar. This has led to the adaptation of dialects and literacy skills that are very different from local languages. They face high anxiety and burnout to learning achievement [38], [39]. The growth of academic resilience in multilingual students is relational and emerges from the connectivity between students and the campus environment [40]. Academic difficulties have an impact on the academic resilience of preservice teacher. More resilient students had generally faced with a higher level of academic difficulty, vice versa. 


\section{CONCLUSION}

Numerous validity and reliability techniques have been carried out to provide confidence to researchers and practitioners in education that the importance of a scale for measuring academic resilience for preservice teachers. This paper serves as a trigger to raise new topic spaces for academic resilience research that focuses on preservice teachers. Academics at universities can measure academic resilience periodically to find out the problems faced by students so that they can signal the vulnerability of students who have slumped academically. Researchers are advised to use the measurement scale studied in this research comprehensively to trace the academic resilience of preservice teachers. Likewise, practitioners in psychology and physical coaching programs for students suffering from difficulties by utilizing the new measurement scale have been presented. Future research can be continued in more specific areas of expertise, such as skills, numerical and verbal skills, micro-teaching abilities, and preservice teacher competencies.

\section{ACKNOWLEDGEMENTS}

The authors are grateful for various parties' assistance, especially the Universitas Negeri Malang, which has provided funding support for this study in the Dissertation Research scheme.

\section{REFERENCES}

[1] M. L. Brewer, et al., "Resilience in higher education students: A scoping review," High. Educ. Res. Dev., vol. 38, no. 6, pp. 1105-1120, 2019, doi: 10.1080/07294360.2019.1626810.

[2] I. Seçer and S. Ulas, "The Mediator Role of Academic Resilience in the Relationship of Anxiety Sensitivity, Social and Adaptive Functioning, and School Refusal With School Attachment in High School Students," Front. Psychol., vol. 11, pp. 1-12, 2020, doi: 10.3389/fpsyg.20200.00557.

[3] P. Walsh, P. A. Owen, N. Mustafa, and R. Beech, "Learning and teaching approaches promoting resilience in student nurses: An integrated review of the literature," Nurse Educ. Pract., vol. 45, no. 2, 2020, doi: 10.1016/j.nepr.2020.102748.

[4] S. Kuldas, S. Hashim, and H. N. Ismail, "Malaysian adolescent students' needs for enhancing thinking skills, counteracting risk factors and demonstrating academic resilience," Int. J. Adolesc. Youth, vol. 20, no. 1, pp. 32-47, 2015, doi: 10.1080/02673843.2014.973890.

[5] A. J. Martin, "Academic buoyancy and academic resilience: Exploring 'everyday'and 'classic'resilience in the face of academic adversity," Sch. Psychol. Int., vol. 34, no. 5, pp. 488-500, 2013, doi: 10.1177/0143034312472759.

[6] R. Dewi, M. F. Rahmadana, W. Pangaribuan, and M. B. Dalimunthe, "Self-Resilience Model of Drug Initiation and Drug Addiction (A Structural Equation Model Approach)," Arch. Psychiatry Res., vol. 56, no. 1, pp. 5-18, Feb. 2020, doi: 10.20471/may.2020.56.01.01.

[7] M. A. Zimmerman, "Resiliency Theory: A Strengths-Based Approach to Research and Practice for Adolescent Health,” Heal. Educ. Behav., vol. 40, no. 4, pp. 381-383, 2013, doi: 10.1177/1090198113493782.

[8] A. S. Masten, "Ordinary magic: Resilience processes in development," Am. Psychol., vol. 56, no. 3, pp. 227-38, 2001, doi: 10.1037//0003-066X.56.3.227.

[9] R. R. Greene, C. Galambos, and Y. Lee, "Resilience theory: Theoretical and professional conceptualizations," $J$. Hum. Behav. Soc. Environ., vol. 8, no. 4, pp. 75-91, 2004, doi: 10.1300/J137v08n04_05.

[10] S. Cassidy, "The Academic Resilience Scale (ARS-30): A new multidimensional construct measure," Front. Psychol., vol. 7, 2016, doi: 10.3389/fpsyg.2016.01787.

[11] M. A. Chisholm-Burns, C. A. Spivey, E. Sherwin, J. Williams, and S. Phelps, "Development of an instrument to measure academic resilience among pharmacy students," Am. J. Pharm. Educ., vol. 83, no. 6, pp. 1337-1390, 2019, doi: $10.5688 /$ ajpe6896.

[12] T. L. Hanson and J.-O. Kim, Measuring resilience and youth development: the psychometric properties of the Healthy Kids Survey. (Issues \& Answers Report, REL 2007-No. 034). Washington, DC: U.S. Department of Education, Institute of Education Sciences, National Center for Education Evaluation and Regional Assistance, Regional Educational Laboratory West, 2007.

[13] M. Turner, S. Holdsworth, and C. M. Scott-Young, "Resilience at University: the development and testing of a new measure," High. Educ. Res. Dev., vol. 36, no. 2, pp. 386-400, 2017, doi: 10.1080/07294360.2016.1185398.

[14] A. J. Martin and H. W. Marsh, "Academic resilience and its psychological and educational correlates: A construct validity approach," Psychol. Sch., vol. 43, no. 3, pp. 267-281, 2006, doi: 10.1002/pits.20149.

[15] M. Yildirim and F. Ç. Tanriverdi, "Social support, resilience and subjective well-being in college students," $J$. Posit. Sch. Psychol., vol. 5, no. 2, pp. 127-135, 2020, doi: 10.47602/jpsp.v5i2.229.

[16] X. Chen, J. Zhong, M. Lou, and M. Lu, "Academic Self-Efficacy, Social Support, and Professional Identity Among Preservice Special Education Teachers in China," Front. Psychol., vol. 11, pp. 1-10, 2020, doi: 10.3389/fpsyg.2020.00374.

[17] J. J.-L. Chen, "Relation of academic support from parents, teachers, and peers to Hong Kong adolescents' academic achievement: The mediating role of academic engagement," Genet. Soc. Gen. Psychol. Monogr., vol. 131, no. 2, pp. 77-127, 2005, doi: 10.3200/MONO.131.2.77-127. 
[18] B. Jowkar, O. Friborg, and O. Hjemdal, "Cross-cultural validation of the Resilience Scale for Adults (RSA) in Iran," Scand. J. Psychol., vol. 51, no. 5, pp. 418-425, 2010, doi: 10.1111/j.1467-9450.2009.00794.x.

[19] A. Coronado-Hijón, "Academic resilience: A transcultural perspective," Procedia-Social Behav. Sci., vol. 237, pp. 594-598, 2017, doi: 10.1016/j.sbspro.2017.02.013.

[20] B. N. Frisby, A. M. Hosek, and A. C. Beck, "The role of classroom relationships as sources of academic resilience and hope," Commun. Q., vol. 68, no. 3, pp. 289-305, 2020, doi: 10.1080/01463373.2020.1779099.

[21] A. Sandoval-Hernández and P. Białowolski, "Factors and conditions promoting academic resilience: a TIMSSbased analysis of five Asian education systems," Asia Pacific Educ. Rev., vol. 17, no. 3, pp. 511-520, 2016, doi: 10.1007/s12564-016-9447-4.

[22] T. Agasisti, F. Avvisati, F. Borgonovi, and S. Longobardi, "Academic resilience: What schools and countries do to help disadvantaged students succeed in PISA," OECD Education Working Papers, No. 167, OECD Publishing, Paris, 2018, doi: 10.1787/e22490ac-en.

[23] J. Dohaney, M. de Róiste, R. A. Salmon, and K. Sutherland, "Benefits, barriers, and incentives for improved resilience to disruption in university teaching," Int. J. Disaster Risk Reduct., vol. 50, Nov. 2020, doi: 10.1016/j.ijdrr.2020.101691.

[24] A. S. Masten, "Resilience Theory and Research on Children and Families: Past, Present, and Promise," J. Fam. Theory Rev., vol. 10, no. 1, pp. 12-31, 2018, doi: 10.1111/jttr.12255.

[25] T. Prickett, J. Walters, L. Yang, M. Harvey, and T. Crick, "Resilience and Effective Learning in First-Year Undergraduate Computer Science," in Proceedings of the 2020 ACM Conference on Innovation and Technology in Computer Science Education, 2020, pp. 19-25, doi: 10.1145/3341525.3387372.

[26] M. Sarwar, H. Inamullah, N. Khan, and N. Anwar, "Resilience and academic achievement of male and female secondary level students in Pakistan," J. Coll. Teach. Learn., vol. 7, no. 8, pp. 19-24, 2010, doi: 10.19030/tlc.v7i8.140.

[27] A. L. DucFworth and P. D. Quinn, "Development and validation of the Short Grit Scale (GritYS)," J. Pers. Assess., vol. 91, no. 2, pp. 166-174, 2009, doi: 10.1080/00223890802634290.

[28] J. W. Creswell, Research design: Quantitative, qualitative and mixed methods, 4th ed. United States of America: Thousand Oaks, CA: Sage, 2014.

[29] J. F. Hair Jr, G. T. M. Hult, C. Ringle, and M. Sarstedt, A primer on partial least squares structural equation modeling (PLS-SEM). Sage Publications, 2014.

[30] H. Retnawati, Reliability validity and item characteristics, (in Indonesia). Yogyakarta: Parama, 2016.

[31] D. Mardapi, Educational Measurement, Assessment and Evaluation, 2nd ed. (in Indonesia). Yogyakarta: Parama, 2017.

[32] D. L. Streiner, G. R. Norman, and J. Cairney, Health measurement scales: a practical guide to their development and use. Oxford University Press, USA, 2015.

[33] I. Meneghel, I. M. Martinez, M. Salanova, and H. de Witte, "Promoting academic satisfaction and performance: Building academic resilience through coping strategies," Psychol. Sch., vol. 56, no. 6, pp. 875-890, 2019, doi: 10.1002/pits.22253.

[34] J. J. Cutuli, J. E. Herbers, A. S. Masten, and M.-G. J. Reed, "Resilience in development," in The Oxford Handbook of Positive Psychology, 3rd Ed. Oxford University Press, 2018, doi: 10.1093/oxfordhb/9780199396511.013.9.

[35] M. P. Penna, M. Agus, M. Peró-Cebollero, J. Guàrdia-Olmos, and E. Pessa, "The use of imagery in statistical reasoning by university undergraduate students: a preliminary study,” Qual. \& Quant., vol. 48, no. 1, pp. 173-187, 2014, doi: 10.1007/s11135-012-9757-5.

[36] F. Reinhold, et al., "The role of spatial, verbal, numerical, and general reasoning abilities in complex word problem solving for young female and male adults," Math. Educ. Res. J., vol. 32, no. 2, pp. 189-211, 2020, doi: 10.1007/s13394-020-00331-0.

[37] E. Hwang and S. Shin, "Characteristics of nursing students with high levels of academic resilience: A crosssectional study," Nurse Educ. Today, vol. 71, pp. 54-59, 2018, doi: 10.1016/j.nedt.2018.09.011.

[38] B. A. Kelsen, "Exploring public speaking anxiety and personal disposition in EFL presentations," Learn. Individ. Differ., vol. 73, pp. 92-101, 2019, doi: 10.1016/j.lindif.2019.05.003.

[39] C. Liu, J. He, C. Ding, X. Fan, G.-J. Hwang, and Y. Zhang, "Self-oriented learning perfectionism and English learning burnout among EFL learners using mobile applications: The mediating roles of English learning anxiety and grit," Learn. Individ. Differ., vol. 88, May 2021, doi: 10.1016/j.lindif.2021.102011.

[40] M. K. Willard-Traub, "Learning Resilience from Multilingual Students," Pedagogy, vol. 19, no. 2, pp. 323-338, 2019, doi: 10.1215/15314200-7295985. 